\title{
Microbial bioavailability regulates organic matter preservation in marine sediments
}

\author{
K. A. Koho ${ }^{1}$, K. G. J. Nierop ${ }^{1}$, L. Moodley ${ }^{2}$, J. J. Middelburg ${ }^{1,2}$, L. Pozzato ${ }^{2}$, K. Soetaert ${ }^{2}$, J. van der Plicht ${ }^{3}$, and \\ G-J. Reichart ${ }^{1,4}$ \\ ${ }^{1}$ Geochemistry, Faculty of Geosciences, Utrecht University, P.O. Box 80.021, 3508 TA Utrecht, the Netherlands \\ ${ }^{2}$ Department of Ecosystem Studies, Royal Netherlands Institute for Sea Research-Yerseke, Korringaweg 7 , \\ 4401 NT Yerseke, the Netherlands \\ ${ }^{3}$ Center for Isotope Research, Groningen University, Nijenborgh 4, 9747 AG Groningen, the Netherlands \\ ${ }^{4}$ Alfred Wegener Institut for Polar and Marine Research, Bremerhaven, Germany
}

Correspondence to: K. A. Koho (k.a.koho@uu.nl)

Received: 23 August 2012 - Published in Biogeosciences Discuss.: 24 September 2012

Revised: 14 January 2013 - Accepted: 29 January 2013 - Published: 20 February 2013

\begin{abstract}
Burial of organic matter (OM) plays an important role in marine sediments, linking the short-term, biological carbon cycle with the long-term, geological subsurface cycle. It is well established that low-oxygen conditions promote organic carbon burial in marine sediments. However, the mechanism remains enigmatic. Here we report biochemical quality, microbial degradability, OM preservation and accumulation along an oxygen gradient in the Indian Ocean. Our results show that more OM, with biochemically higher quality, accumulates under low oxygen conditions. Nevertheless, microbial degradability does not correlate with the biochemical quality of OM. This decoupling of OM biochemical quality and microbial degradability, or bioavailability, violates the ruling paradigm that higher quality implies higher microbial processing. The inhibition of bacterial OM remineralisation may play an important role in the burial of organic matter in marine sediments and formation of oil source rocks.
\end{abstract}

\section{Introduction}

Degradation of marine organic matter (OM) begins in the water column, immediately upon the death of marine organisms, and continues at and below the sediment-water interface (Hedges et al., 2000). Oxygen deficiency of the depositional setting has been shown to favour the formation of organic-rich deposits (Hartnett et al., 1998) and oil source rocks (Demaison and Moore, 1980; Gélinas et al., 2001), implying lower degradation rates of organic matter under low oxygen conditions. However, this paradigm has been challenged (e.g. Canfield, 1994), and many other parameters including enhanced primary productivity (Pedersen and Calvert, 1990), sorption to surfaces (Keil et al., 1994a) and high sediment-accumulation rates (Hedges and Keil, 1995) may be associated with the formation of OM-rich sediments.

OM remineralisation in marine sediments is mainly attributed to bacteria (Turley et al., 2000). A wide array of bacteria are required to carry out successful OM degradation, of which hydrolytic and fermentative bacteria play a key role, being able to break down (hydrolyse) complex polymeric compounds into smaller, more soluble and digestible products. Therefore, the activity of these bacteria is often proposed to limit OM degradation rates (Tyson, 1995; Arnosti, 2004). However, OM remineralisation is also influenced by macrofauna. For example, experimental work has shown that under oxic bottom-water conditions, the redistribution and transport of OM from surface sediments to deeper units makes OM more available to a wider bacterial community, and thus substantially stimulates bacterial OM remineralisation (Kristensen and Mikkelsen, 2003; Van Nugteren et al., 2009). Furthermore, macrofaunal bioirrigation will bring oxygen deeper into the sediment and increase solute transport, stimulating microbial activity and net remineralisation (e.g. Aller, 1982, 1994; Aller and Aller, 1998). 
Macrofauna also degrade OM directly by ingestion and subsequent mineralisation. Macrofaunal deposit feeders employ a high intensity digestive system, whereas bacteria use low intensity hydrolysis based on extracellular enzymes (Mayer et al., 2001). These different degradation pathways may lead to variations in the biochemical composition of remaining sedimentary OM (Woulds et al., 2012). Specifically, macrofaunal digestion (manipulation) has been suggested to enhance the degradability of OM by microbes (Van Nugteren et al., 2009). Similarly, in soils, particle manipulation by animals is known to promote microbial OM degradation (Brussaard et al., 1997).

From a geological and oil-source rock perspective, it is important to understand which fraction of the OM survives the early degradation stages and is left behind in the rock record, potentially becoming a hydrocarbon source. Traditionally, OM degradation (or OM bioavailability) has been observed to co-vary with OM biochemical quality and quantity, with higher biochemical quality and quantity typically leading to higher remineralisation rates (Henrichs, 1992; Cowie et al., 1995). Robust and commonly applied indirect indicators of biochemical quality of sedimentary OM are the concentrations of chlorophyll $a(\mathrm{Chl} a)$ and other intact (or non-altered) pigments. The degradation products of Chl $a$, phaeopigments (phaeo), in turn serve as indicators of more degraded OM, and the ratio of the two is a commonly applied to examine the quality of sedimentary OM (e.g. Jeffrey and Vesk, 1997; Woulds and Cowie, 2009). Amino acid composition provides another powerful indirect tool for examination of $\mathrm{OM}$ biochemical composition, with certain amino acids becoming preferentially enriched (e.g. $\beta$-alanine and $\gamma$-aminobutyric acid) during degradation while others (e.g. aspartic acid and glutamic acid) are lost (e.g. Cowie and Hedges, 1992, 1994; Dauwe and Middelburg, 1998; Dauwe et al., 1999). Moreover, a quantitative degradation index (DI), based on a range of amino acids and reflecting the progressive compositional change during OM remineralisation, provides another tool to assess the biochemical composition of OM (Dauwe et al., 1999; Vandewiele et al., 2009).

The aim of this study was to investigate two independent parameters - microbial mineralisation and biochemical quality - in order to study the drivers and constraints of OM degradation in marine sediments. Previous work has investigated the biochemical quality of OM in Arabian Sea sediments (e.g. Cowie and Levin, 2009; Vandewiele et al., 2009; Woulds and Cowie, 2009), and, through an experimental approach, microbial degradation in these sediments (Moodley et al., 2011). However, a combined study of both parameters is lacking. Here we report the biochemical quality of OM, including amino acid and pigment analyses, and the potential (oxic) microbial remineralisation rates of $\mathrm{OM}$ along a bottom-water oxygen gradient. In addition, biological mixing, the result of metazoan activity, was assessed by means of downcore ${ }^{14} \mathrm{C}$, phaeopigment and ${ }^{210} \mathrm{~Pb}$ profiles. OM accumulation rates were estimated using ${ }^{14} \mathrm{C}$-dating.

\section{Materials and methods}

The Arabian Sea is characterised by a pronounced mid-water column oxygen minimum zone (OMZ), which is sustained through monsoon-driven high surface water primary productivity and relatively weak bottom-water ventilation via Antarctic Intermediate Water (Wyrtki, 1973). The modernday OMZ $\left(\mathrm{O}_{2}<22 \mu \mathrm{M}\right.$ after Helly and Levin, 2004) extends from \pm 100 to $\pm 1400 \mathrm{~m}$ water depth with some spatial and seasonal variability. However, the core of the OMZ is relatively stable, with bottom-water oxygen (BWO) values falling to $2 \mu \mathrm{M}$ (Cowie and Levin, 2009). The intensity of Arabian Sea OMZ appears to fluctuate on orbital and suborbital time scales, with minimum OMZ intensity coinciding with low productivity and high winter mixing during the climatic cooling in the North Atlantic (Reichart et al., 1998).

In January 2009, during the PASOM (process study on the Arabian Sea oxygen minimum zone) cruise in the northeastern Arabian Sea, undisturbed surface sediments were collected with a multiple corer, along a BWO gradient ranging from $2 \mu \mathrm{M}$ to $80 \mu \mathrm{M}$, on the Murray Ridge. The studied sites also lie along a depth transect ranging from $900 \mathrm{~m}$ to $3000 \mathrm{~m}$ water depth (Fig. 1, Table 1). In addition to coring, a CTD profile, including an attached oxygen sensor (SeaBird SBE43, accuracy $2 \%$ ), was determined at each station to monitor the water-column properties.

\subsection{Degradability potential of organic matter}

To assess the potential microbial decomposition of OM under oxic conditions, we performed a series of oxic sediment incubations where $\mathrm{CO}_{2}$ production per unit of $\mathrm{OM}$ was quantified (Dauwe et al., 2001). We decided that an oxic approach was the most suitable for indicating the potential net rates of OM remineralisation as oxic conditions have been shown to produce higher, or similar, remineralisation rates than anoxic ones (e.g. Hulthe et al., 1998; Moodley et al., 2011). Nevertheless, some bias in the potential availability rates may result from the adaptation of different bacterial communities. However, we believe this is unlikely to be of a major concern as bacteria are ubiquitous (Fenchel and Finlay, 2004; De Wit and Bouvier, 2006). Furthermore, very similar carbon remineralisation rates were observed for surface sediments of the eastern Arabian Sea OMZ sediment, where both anoxic and oxic incubations were performed (Moodley et al., 2011).

The incubations to assess the in situ OM microbial bioavailability and to quantify the organic carbon $\left(\mathrm{C}_{\mathrm{org}}\right)$ remineralisation through $\mathrm{CO}_{2}$ production were performed in duplicate on homogenised surface sediments (top $3 \mathrm{~cm}$ ), following the main protocol outlined in Moodley et al. (2011). Here in short: following core recovery, samples were stored in darkness, in sealed plastic bags at $4{ }^{\circ} \mathrm{C}$. This was chosen over freezing of the sediment, which could have been detrimental to the bacterial community. Storage in sealed plastic bags most likely also resulted in anoxic conditions, although 

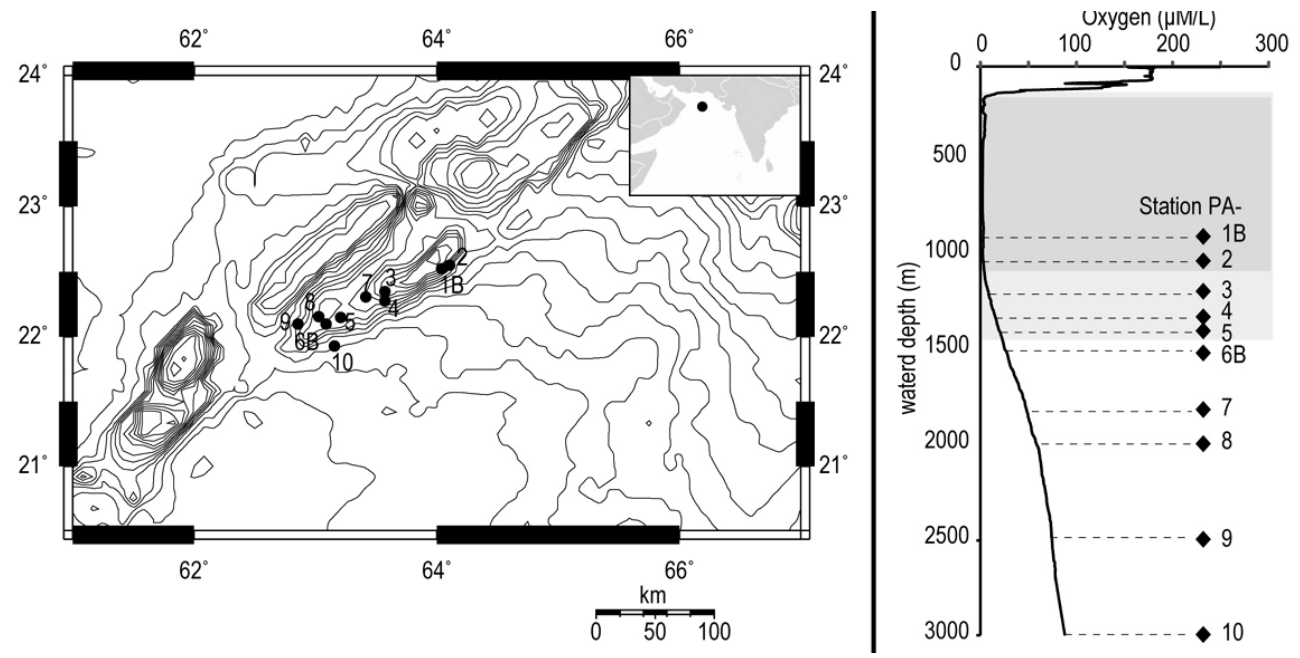

Fig. 1. Left: map of Murray Ridge, Arabian Sea, showing the station locations with an annex of the Indian Ocean with the Murray Ridge indicated with a solid symbol. Right: water-column profile of dissolved oxygen in the study area. Water depth and BWO content of each station shown. Dark grey shaded area $=$ core of the OMZ, BWO content $<5 \mu \mathrm{M}$; light grey shaded area $=\mathrm{OMZ}$, BWO content $<22 \mu \mathrm{M}$ (or $\left.0.5 \mathrm{~mL} \mathrm{~L}^{-1}\right)$.

this was not monitored. The incubations were initiated after two months and performed in darkness at $10^{\circ} \mathrm{C}$. The incubations were carried out in $80 \mathrm{~mL}$ bottles. Into each bottle $10 \mathrm{~mL}$ of homogenised sediment was inserted. The bottles were then filled with well-aerated $0.2 \mu \mathrm{m}$-filtered seawater (low-nutrient deep Atlantic water). Total water content, as well as accurate conversion of wet and dry weight sediment, was obtained by direct weighing. Throughout the experiment, the bottles were periodically shaken to mix the slurry. At the end of the incubations the oxygen content was measured with an oxygen optode (Presens, Germany). The oxygen content in each bottle at the end of the incubation was always $>20 \mu \mathrm{M}$.

At the start of the experiment, sediment was sub-sampled for background analysis $\left(\mathrm{C}_{\mathrm{org}}\right.$, total hydrolysable amino acids, grain size, Sect. 2.2). At the end of the incubations (18 days) the sediment from duplicate bottles was combined (due to expected low concentration of polar lipid-derived fatty acids, PLFAs) for PLFA extraction used to estimate bacterial biomass (Sect. 2.2).

The OM reactivity, expressed as a half-life, was calculated as $-\ln (0.5) / k$ with $k$ (decay constant) based on the quotient of $\mathrm{CO}_{2}$ production and $\mathrm{C}_{\mathrm{org}}$ content per $\mathrm{mL}$ wet sediment (Hargrave and Phillips, 1981).

\subsection{Analytical measurements}

Organic carbon and nitrogen contents of ground freeze-dried sediments were measured using an elemental analyzer following acidification to remove any carbonate (Nieuwenhuize et al., 1994).

The total hydrolysable amino acids (THAA) were measured after Vandewiele et al. (2009). Here in short: samples of $0.1 \mathrm{~g}$ freeze-dried sediment were hydrolysed $(6 \mathrm{~N} \mathrm{HCl}$, $110^{\circ} \mathrm{C}, 20 \mathrm{~h}$, under $\mathrm{N}_{2}$ atmosphere). To measure total concentrations, $0.1 \mathrm{~mL}$ of the hydrolysate was added to $2 \mathrm{~mL}$ potassium borate buffer ( $\mathrm{pH} 10)$ and neutralised with $0.1 \mathrm{~mL}$ of $6 \mathrm{~N} \mathrm{NaOH}$. The solutions were vortexed and left standing at room temperature for $1 \mathrm{~h}$, after which they were vortexed again to eliminate any ammonium present in the mixture. Fluorescent derivatives were obtained by adding $0.2-0.4 \mathrm{~mL}$ of the solutions and an equal amount of orthophthaldialdehyde reagents to $2 \mathrm{~mL}$ phosphate buffer ( $\mathrm{pH} 8)$ in a cuvette and vortexing the solution. After $5 \mathrm{~min}$, total concentrations were determined by measuring the fluorescence in a spectrofluorometer (excitation wavelength: $340 \mathrm{~nm}$; emission wavelength: $455 \mathrm{~nm}$ ). By comparison with a standard amino acid mixture (Sigma), these measurements were then converted to concentrations. Individual amino acids were determined by reverse-phase HPLC after Fitznar et al. (1999). The obtained THAA distribution was used to calculate the DI index, which translates subtle differences in the amino acid composition into one number indicative of the degradation state of particulate OM: from -2 for extensively degraded to +1 for fresh algae (Dauwe et al., 1999).

At the end of the slurry incubations, the sediment was freeze-dried and subsequently analyzed for polar lipidderived fatty acid (PLFA) content in order to estimate the bacterial biomass, which was based on concentration of bacteria-specific PLFAs (i14C:0, i15C:0, a15C:0 and i16C:0) after Middelburg et al. (2000). Here in short: lipids were extracted from $3 \mathrm{~g}$ of sediment (wet weight) with a modified Bligh and Dyer extraction (Boschker et al., 1999). The lipid extract was then further fractionated on silicic acid $(60$, Merck) into different polarity classes by sequential eluting with chloroform, acetone and methanol. The 
methanol fraction, which contained the PLFAs, was derivatized using mild alkaline methanolysis to yield fatty acid methyl esters (FAMEs). Internal FAME standards of 12:0 and 19:0 were used. The analyses were carried out using a gas chromatography combustion isotope ratio mass spectrometry (GC-c-IRMS).

The grain size measurements of the surface sediment (top $3 \mathrm{~cm}$ ) were performed using a Malvern Particle Analyzer. The sediment was not acidified prior to analyses.

Sedimentary pigments were analyzed for all ten stations. Onboard, the top $10 \mathrm{~cm}$ of a multicore subcore $(6 \mathrm{~cm}$ diameter) was subsampled into 10 slices: the top $2 \mathrm{~cm}$ every $0.5 \mathrm{~cm}$, from $2-6 \mathrm{~cm}$ every $1 \mathrm{~cm}$ and from $6-10 \mathrm{~cm}$ at every $2 \mathrm{~cm}$. The samples were stored at $-80^{\circ} \mathrm{C}$, and freeze-dried prior to pigment extraction in $10 \mathrm{~mL}$ of acetone : water $(90: 10)$. The full pigment composition was gained through application of high-performance liquid chromatography (HPLC) equipped with a $\mathrm{C}_{18}$ reverse phase column. See Barranguet et al. (1998) for the full methodological description. The calibration was based on working standards prepared from commercially available compounds (DHI, Denmark). The pigment concentrations are reported per $\mu \mathrm{g} \mathrm{g}^{-1}$ of sediment. The pigment inventories were calculated as a depth-integrated sum of pigments in the top $10 \mathrm{~cm}$ of sediment.

\subsection{Bioturbation and sediment mixing: ${ }^{210} \mathrm{~Pb}$ and ${ }^{14} \mathrm{C}$ profiles}

Downcore ${ }^{210} \mathrm{~Pb}$ profiles were measured for four stations (water depths: $1013 \mathrm{~m}, 1172 \mathrm{~m}, 1306 \mathrm{~m}$ and $1495 \mathrm{~m}$ ). Samples were taken from the top $6 \mathrm{~cm}$ of sediment. The top $2 \mathrm{~cm}$ was sampled at every $0.5 \mathrm{~cm}$ and thereafter at $1 \mathrm{~cm}$ intervals. The ${ }^{210} \mathrm{~Pb}$ activity in $100 \mathrm{mg}$ dry weight of sample was measured at Royal NIOZ by $\alpha$-spectrometry of its granddaughter ${ }^{210} \mathrm{Po}$, which was precipitated on silver after digestion of sample in an acid solution (Boer et al., 2006). It should be noted that in open marine sediments, like the Murray Ridge, with relatively low sediment accumulation rates (typically a few $\mathrm{cm} \mathrm{kyr}{ }^{-1}$ ), the down-core changes in ${ }^{210} \mathrm{~Pb}$ (and phaeopigment) content are due to particle mixing (bioturbation) rather than accumulation. If the ${ }^{210} \mathrm{~Pb}$ profile would represent isotope decay, and thus reflect the sedimentation rate, it should not penetrate the surficial sediments but complete decay within the first $\mathrm{cm}$ of the sediment. The same principle applies to phaeopigments, however, at stations where the surficial pigment concentrations are very low, microbial degradation may play a role.

The ${ }^{14} \mathrm{C}$-AMS dating was performed on carbonate from handpicked planktonic foraminiferal tests from three depth intervals (top, middle, bottom) of the multicores. The ${ }^{14} \mathrm{C}$ dating was carried out at each station. The ${ }^{14} \mathrm{C}$ ages were corrected using a marine reservoir age of $400 \mathrm{yr}$ and calibrated using the Int09 calibration curve with CALIB software package version 6.0.1 (Stuiver and Reimer, 1993).

\subsection{Carbon accumulation rates}

Organic carbon accumulation, or burial, rates were based on the $\mathrm{C}_{\text {org }}$ content of the top $3 \mathrm{~cm}$ of sediment. The surface $\mathrm{C}_{\text {org }}$ values in the $\mathrm{OMZ}$ sediments can be taken to represent the burial values, as the downcore profiles are relatively constant (Vandewiele et al., 2009; Kraal et al., 2012). Furthermore, the typical decrease in $\mathrm{C}_{\text {org }}$ content, which may be anticipated at the oxic sites occurred within the top $3 \mathrm{~cm}$ of the sediment (data not shown). In fact, if using deeper sedimentary $\mathrm{C}_{\text {org }}$ content (e.g $18-20 \mathrm{~cm}$ depth) to calculate carbon burial rates a slight increase rather than decrease is observed, although the pattern remains the same. As the trend in the burial calculations remains the same if using the top $3 \mathrm{~cm}$ or a deeper horizon, we believe that our burial estimates are valid in their current form.

For the $0-3 \mathrm{~cm}$ sediment interval, the dry bulk density was determined for each station by measuring the weight of a known volume of freeze dried sediment (data not shown). The accumulation rates were inferred from ${ }^{14} \mathrm{C}$ ages. If a clear linear average age vs. depth correlation was not possible, maximum and minimum accumulation rates (and average) were calculated. No $\mathrm{C}_{\text {org }}$ accumulation rate was calculated for the station from $1495 \mathrm{~m}$ water depth as no clear relationship between ${ }^{14} \mathrm{C}$-data and depth was observed.

\section{Results and discussion}

\subsection{Sediment characteristics: OM quantity and biochemical quality}

None of our stations contained clearly laminated sediments, although the four deepest sites outside the OMZ (water depth 1791-3010 m) could be argued to show some subsurface very fine scale lamina (Fig. 2). However, distinct changes in the sediment characteristics were observed along the oxygen gradient, with respect to colour (Fig. 2), $\mathrm{C}_{\text {org }}$ content, $\mathrm{C}_{\text {org }}$ accumulation rates and biochemical composition (Fig. 3). The OMZ stations at $885 \mathrm{~m}$ and $1013 \mathrm{~m}$ water depth, with BWO contents of $2-3 \mu \mathrm{M}$, were distinctly darker (darkolive brown vs. olive brown) than sediments from somewhat deeper sites (depth: $1172 \mathrm{~m}$ to $1379 \mathrm{~m}$; with $\mathrm{BWO}$ ranging 5-17 $\mu \mathrm{M}$ ). With BWO increasing to $27 \mu \mathrm{M}$ at $1495 \mathrm{~m}$ water depth, a colour change from light-olive-brown to more greyish sediment underneath was seen in the top $1 \mathrm{~cm}$, indicating a shallow oxidation front. However, clearly bioturbated sediments with red-brownish surfaces overlying more grey sediments were not seen until $1791 \mathrm{~m}$ water depth with a BWO content of $45 \mu \mathrm{M}$.

All measured parameters indicative of $\mathrm{OM}$ quantity in recent sediments, $\mathrm{C}_{\text {org }}$ (Fig. 3a), $\mathrm{C}_{\text {org }}$ accumulation (Fig. 3b), total pigment inventory (Fig. 3c) and total hydrolysable amino acids (Fig. 3d), showed a clear exponential decline with increasing BWO content. The 
Table 1. Original station name, station positions, water depth, bottom-water oxygen (BWO) content, median grain size and silt content. In the text and figures stations are referred to according to their water depth.

\begin{tabular}{lrrrrrr}
\hline $\begin{array}{l}\text { Station } \\
\text { PASOM- }\end{array}$ & $\begin{array}{r}\text { Lat } \\
(\mathrm{N})\end{array}$ & $\begin{array}{r}\text { Lat } \\
(\mathrm{E})\end{array}$ & $\begin{array}{r}\text { Depth } \\
(\mathrm{m})\end{array}$ & $\begin{array}{r}\text { BWO } \\
(\mu \mathrm{M})\end{array}$ & $\begin{array}{r}\text { Median } \\
(\mu \mathrm{m})\end{array}$ & $\begin{array}{r}\text { Silt } \\
(\%)\end{array}$ \\
\hline $1 \mathrm{~B}$ & $22^{\circ} 32.9^{\prime}$ & $64^{\circ} 02.4^{\prime}$ & 885 & 2.1 & 35.4 & 70.4 \\
2 & $22^{\circ} 33.9^{\prime}$ & $64^{\circ} 03.8^{\prime}$ & 1013 & 2.6 & 41.2 & 63.3 \\
3 & $22^{\circ} 19.9^{\prime}$ & $63^{\circ} 36.0^{\prime}$ & 1172 & 5.1 & 38.6 & 65.2 \\
4 & $22^{\circ} 18.0^{\prime}$ & $63^{\circ} 36.0^{\prime}$ & 1306 & 13.8 & 29.6 & 71.4 \\
5 & $22^{\circ} 09.3^{\prime}$ & $63^{\circ} 12.8^{\prime}$ & 1379 & 16.8 & 74.7 & 46.5 \\
$6 \mathrm{~B}$ & $22^{\circ} 04.7^{\prime}$ & $63^{\circ} 04.5^{\prime}$ & 1495 & 26.8 & 27.4 & 73.8 \\
7 & $22^{\circ} 18.5^{\prime}$ & $63^{\circ} 24.5^{\prime}$ & 1791 & 45.2 & 16.6 & 92.2 \\
8 & $22^{\circ} 08.7^{\prime}$ & $63^{\circ} 01.1^{\prime}$ & 1970 & 56.9 & 15.2 & 91.8 \\
9 & $22^{\circ} 06.3^{\prime}$ & $62^{\circ} 53.7^{\prime}$ & 2470 & 66.3 & No data & No data \\
10 & $21^{\circ} 55.6^{\prime}$ & $63^{\circ} 10.6^{\prime}$ & 3010 & 76.9 & 14.8 & 94.7 \\
\hline
\end{tabular}

exponentialrelationship between $\mathrm{C}_{\mathrm{org}}$ content and BWO in the Arabian Sea OMZ closely corresponds to data from Slater and Kroopnick (1984).

The biochemical composition of OM changes during remineralisation due to preferential loss of reactive compounds and accumulation of other, more refractory compounds (Cowie and Hedges, 1992; Dauwe et al., 1999). Therefore, biochemical OM quality indicators, like amino acids and photosynthetic pigments, provide powerful tools to assess the extent of the OM degradation. Our biochemical OM quality indicators showed clear linear trends with the BWO content, with the highest quality coinciding with the lowest oxygen concentrations in the OMZ (Fig. 3e, f). The quantitative amino-acid degradation index (DI), which is based on subtle changes in amino acids composition reflecting the progressive compositional change during OM remineralisation (Dauwe et al., 1999), ranged from -0.45 to -1.4 and related strongly with the BWO content $\left(R^{2}=0.95, p=<0.001\right)$. As the DI was negative at all sites $(+1$ represents freshly produced algal matter and -2 corresponds to extensively degraded deep-sea sediments; Dauwe et al., 1999; Vandewiele et al., 2009), the OM in the core of the OMZ was moderately degraded. However, extensive degradation (DI $=-1.4$ ) was seen at the deepest better-oxygenated site, consistently with observations on the Pakistan margin (Vandewiele et al., 2009). Similarly, the phytopigment OM quality indicator (the content of Chl $a$ and other intact phytopigments over total pigments) showed a strong relation with the BWO content $\left(R^{2}=0.73, p=0.02\right)$, implying enhanced degradation with elevated bottom-water oxygenation as previously reported by Woulds and Cowie (2009). The pigment index also showed a relation to the DI $\left(R^{2}=0.65, p=0.009\right)$. Clearly, biochemical indices for OM quality consistently show preservation of high quality OM under low oxygen conditions.

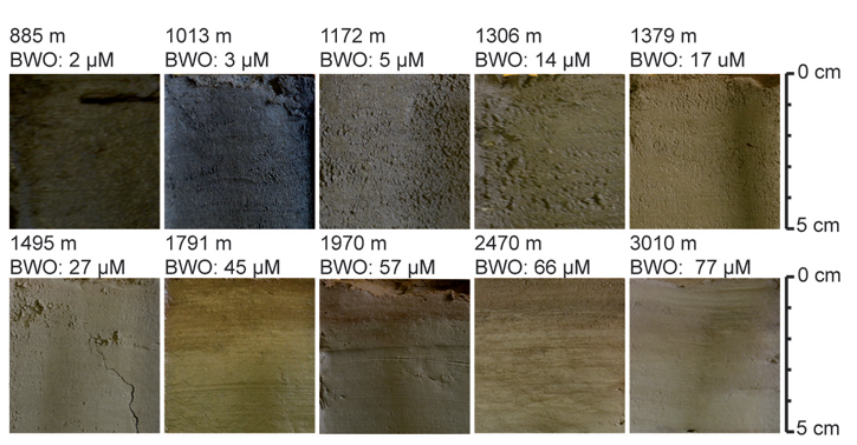

Fig. 2. Images of surface sediments from the studied oxygen transect. First row: stations from $885 \mathrm{~m}$ water depth down to $1379 \mathrm{~m}$ depth. These are located in the $\mathrm{OMZ}$ where bottom-water oxygen (BWO) is less than $22 \mu \mathrm{M}$. Second row: stations from $1495 \mathrm{~m}$ water depth down to $3010 \mathrm{~m}$ depth. These sites are located below the OMZ where BWO ranges from $27 \mu \mathrm{M}$ to $77 \mu \mathrm{M}$.

\subsection{Bacterial biomass and OM (microbial) degradability}

The bacterial biomass was relatively constant averaging $248 \pm 67 \mathrm{mmol} \mathrm{C} \mathrm{m}^{-2}$ and did not show a clear trend along the study transect (Fig. 3g). The only exception was the station located at $2470 \mathrm{~m}$ water depth, where a bacterial biomass minimum $\left(127 \mathrm{mmol} \mathrm{C} \mathrm{m}^{-2}\right)$ was recorded. Nevertheless, our biomass data fit with the general observation that bacterial biomass is rather constant in oceanic sediments, regardless of the depositional setting (Wei et al., 2010). Furthermore, despite the high quantity and high biochemical quality of $\mathrm{OM}$ in the $\mathrm{OMZ}$ sites, the potential remineralisation rates under oxic conditions were remarkably constant along our study transect, averaging $2.01 \pm 0.33 \mathrm{mmol} \mathrm{C} \mathrm{m}^{-2} \mathrm{~d}^{-1}$ (Fig. 3g). Our remineralisation rates are similar to those measured for OMZ sediments along the eastern Arabian Sea and one order of magnitude lower than those for continental shelf sediments (Moodley et al., 2011). Hence, the abundant OM of moderately high quality in OMZ sediments exhibits surprisingly poor microbial degradability (bioavailability). The examination of the OM decay constants $(k)$ derived from the incubation experiments, supports this observation, showing that the $\mathrm{OM}$ accumulating in the $\mathrm{OMZ}$ is significantly less biodegradable than the OM deposited in the oxygenated zone below the OMZ (Mann-Whitney test, 1-tailed, $p<0.005$, $n=18$; Fig. $3 \mathrm{~h}$ ). The resulting average OM half-life for OMZ sediments is $35 \pm 14 \mathrm{yr}$ while the corresponding numbers for the zone below the OMZ is only a half of this $(15 \pm 2 \mathrm{yr}$; not shown). As the incubations were carried under oxic conditions, some bias may result from the adaptation of different bacterial communities. However, we believe this is unlikely to be a major concern as very similar carbon remineralisation rates were observed for surface sediments of the eastern Arabian Sea OMZ sediment, where both anoxic and oxic incubations were performed (Moodley et al., 2011). 

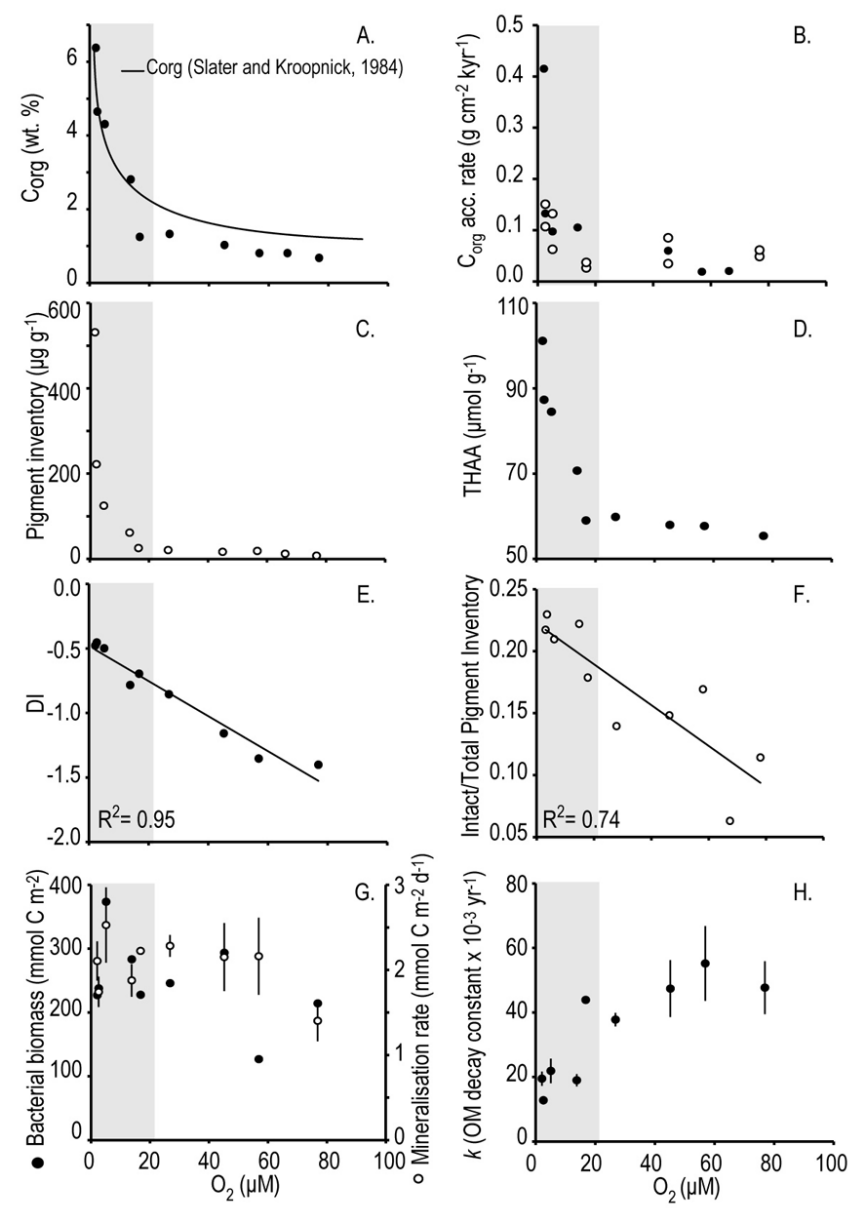

Fig. 3. Organic matter quantity, organic carbon accumulation and biochemical quality indices versus bottom-water oxygen content. (A) Organic carbon with a trend line of Slater and Kroopnick (1984); (B) organic carbon accumulation rates. The solid circles indicate the values based on average sedimentation rates where as the open circles indicate the maximum and minimum accumulation rates. (C) Total pigment inventory; (D) total hydrolysable amino acid content (THAA); (E) DI, the amino acid degradation index; (F) intact/total pigment inventory; (G) bacterial biomass (closed symbol) and mineralisation rate (open symbol); (H) OM decay constant versus BWO content along the studies transect. The area shaded in grey represents the zone where BWO content is $<22 \mu \mathrm{M}$ and invertebrate fauna are accordingly affected by the low $\mathrm{O}_{2}$ concentrations (Levin, 2003). The error bars in plots $\mathrm{G}$ and $\mathrm{H}$ represent the standard deviation of two replicate incubations. No error bars are available for bacterial biomass as the sediment was pooled for bacterial PLFA analyses (G).

Furthermore, it should be noted that our remineralisation rates reflect the potential degradation rates under oxic conditions. Thus, the in situ rates in the OMZ of moderately degraded OM may be expected to be lower due to the near absence of oxygen (Hulthe et al., 1998; Dauwe et al., 2001).

\subsection{OM bioavailability versus biochemical OM quality}

The apparent paradox that biochemical quality and direct microbial bioavailability of $\mathrm{OM}$ are not coupled is intriguing. This is in contrast with the ruling paradigm that less degraded $\mathrm{OM}$, or OM of higher quality as inferred from biochemical composition, is typically more readily degradable (Henrichs, 1992; Cowie et al., 1995; Hedges and Keil, 1995). We suggest that this retardation of OM remineralisation in OMZ sediments may be the controlling parameter for the accumulation of $\mathrm{OM}$ in the $\mathrm{OMZ}$ sediments.

Several mechanisms have been linked to the inhibition of OM remineralisation. For example, physical protection through encapsulation of reactive OM with algaenans, compounds present in algal cell walls, or other hydrolysisresistant matrices may inhibit the remineralisation of $\mathrm{OM}$ of high biochemical quality (Knicker, 2004). However, we do not believe that algaenans play a major role in the protection of $\mathrm{OM}$ in the $\mathrm{OMZ}$ sediments. The relative abundance of amino acids typically found in the algal cell wall, such as of glycine and threonine, were equally abundant in the OMZ sediments $(27.2 \pm 0.4 \%)$ and in sediments outside the OMZ (27.8 $\pm 0.7 \%$; data not shown). Sedimentary OM has also been shown to be commonly enriched in finely grained sediments (e.g. Bordovskiy, 1965; Premuzic et al., 1982; Keil et al., 1994b) and it has been suggested that this may be due to OM association with, or sorption to, mineral surfaces (e.g. Keil et al., 1994a; Mayer, 1994; Hedges and Keil, 1995). In this study, no data for mineral surface area is available. Nevertheless, no correlation was observed between the median grain size or clay content (Table 1) and sedimentary $\mathrm{C}_{\text {org }}$ content (Pearson correlation: $p=0.513, n=9$; and $p=0.247, n=9$, respectively). Moreover, Vandewiele et al. (2009) showed that sediments below the Pakistan OMZ are also enriched in organic carbon when normalised to specific mineral surface area. Therefore, we believe that mineral surface sorption is not the primary preservation mechanism of OM in the OMZ sediments.

OM depolymerisation via extracellular enzymatic hydrolysis has been shown to be the rate-limiting step in OM remineralisation (e.g. Hoppe, 1991; Arnosti, 2004). Microbial remineralisation of OM of high molecular weight substrate typically begins with extracellular enzymatic hydrolysis, which produces compounds small enough to be taken up by a bacterial cell. The typical molecular size limit for microbial uptake is around $600 \mathrm{Da}$ (Weiss et al., 1991). Thus, the inhibition of OM remineralisation may be due to the presence of higher molecular weight compounds, which are not bioavailable to microbes despite their higher biochemical quality (Arnosti and Holmer, 2003). This may also be the case in our OMZ transect, as pyrolysis results indicate relatively higher concentrations of pigment-derived, macromolecular-bound tetrapyrrole compounds in the $\mathrm{OMZ}$ sediments and the absence of these pigment related macromolecules outside the OMZ (K. Nierop, unpublished data). 




Fig. 4. Sediment mixing or bioturbation indicators used in this study. Stations from $885 \mathrm{~m}$ depth down to $1379 \mathrm{~m}$ water depth are located in the $\mathrm{OMZ}$ and stations from $1495 \mathrm{~m}$ depth to $3010 \mathrm{~m}$ depth are located outside the $\mathrm{OMZ}$. Three mixing indicators used: ${ }^{14} \mathrm{C}$ data to give age of sediment in absolute years, and down core phaeopigment and ${ }^{210} \mathrm{~Pb}$ data. Due to various half-lives of the mixing indicators, longterm and short-term mixing can be examined independently, see main body of text for more detail. Light grey shading in the ${ }^{14} \mathrm{C}$ age plots indicates the top $10 \mathrm{~cm}$ of sediment, which is also shown in phaeopigment and ${ }^{210} \mathrm{~Pb}$ profiles. Horizontal, dashed lines indicate the inferred mixing/bioturbation zone. 
Particle manipulation by macrofauna, which have relatively complex digestion pathways and involve many enzymes, makes OM more accessible to microbes by changing the surface area of particles, simultaneously making nutrientrich molecules more easily obtainable (Mayer et al., 2001). Through this mechanism, macrofauna may catalyse microbial degradation, aiding the breakdown of macromolecular compounds and providing bacteria with bioavailable OM. Such particle manipulation by fauna and associated bioturbation would also enhance the diffusion of enzymes, thus accelerating microbial degradation in agreement with the $\mathrm{OM}$ degradation model of Rothman and Forney (2007). A recent in situ labelling study by Hunter et al. (2012) also points out the importance of macrofauna in regulating bacterial carbon and nitrogen uptake in OMZ sediments. In OMZ sediments in the presence of macrofauna (as in this study), OM processing by bacteria was observed to be retarded, occurring only after OM was first processed by macrofauna. The study of Hunter et al. (2012) thus supports the idea that OM particle manipulation by macrofauna mediates heterotrophic bacterial utilisation. In addition, the study of Hunter et al. (2012) is in agreement with the abyssal uptake experiment of Witte et al. (2003) where faunal activity appeared to control bacterial OM uptake. The work of van Nugteren et al. (2009) has also demonstrated enhanced degradation of $\mathrm{OM}$ in the presence of macrofauna.

We suggest that poorly developed macrofaunal communities in the OMZ are responsible for the enhanced preservation of OM in these sediments. Direct macrofaunal data for the Murray Ridge suggest relatively high macrofaunal abundance within the OMZ $\left( \pm 1400 \mathrm{mg} \mathrm{C} \mathrm{m}^{-2}\right.$; Pozzato, 2012), despite the BWO concentrations $(2-3 \mu \mathrm{M})$ being substantially lower than the accepted lower limit of long-term oxygen tolerance of macrofauna $(22 \mu \mathrm{M}$; Levin, 2003). However, the diversity of the macrofaunal community is very low; $65 \%$ of the total biomass (including bacteria) is attributed to the polycheate Linopherus sp. This species is known to live close to the sediment-water interface, where it makes shallow, vertical burrows (Gooday et al., 2009; Levin et al., 2009). Similarly low macrofaunal diversity inside the OMZ has also been highlighted in studies of the adjacent Pakistan margin (Gooday et al., 2009; Hughes et al., 2009). Apparently, these shallow, low-diversity assemblages are less efficient than high-diversity assemblages at manipulating sedimentary $\mathrm{OM}$ into particles which are readily available for bacterial remineralisation.

In the absence of more complete macrofaunal data, we use bioturbation estimates (Fig. 4) as a proxy for macrofaunal activity along the complete transect. Comparing organic carbon accumulation to bioturbation depth Van Der Weijden et al. (1999) showed an inverse relation. The linear ${ }^{14} \mathrm{C}$ age vs. depth relationships at the $885 \mathrm{~m}$ and $1013 \mathrm{~m}$ sites suggest that bioturbation is limited to the very surficial sediments in the OMZ itself, supporting our theory of inefficient sedimentary recycling by the low-diversity macrofaunal assemblage
(Fig. 4). Generally, bioturbation then increases with increasing bottom-water oxygenation. Between $1172 \mathrm{~m}$ and $1379 \mathrm{~m}$ water depth, the bioturbation horizon appears to reach $\pm 4 \mathrm{~cm}$ sediment depth, based on pigment and ${ }^{210} \mathrm{~Pb}$ profiles (Fig. 4). The ${ }^{14} \mathrm{C}$-profiles suggest somewhat deeper mixing for the stations located at $1306 \mathrm{~m}$ and $1379 \mathrm{~m}$ water depth, implying that the long-term mean mixing depth at these stations may be greater (up to $10 \mathrm{~cm}$ ). Such deep mixing may be related to the burrowing activity of Zoophycos (Leuschner et al., 2002). At $1791 \mathrm{~m}$ water depth the bioturbation zone reaches down to $\pm 6-7 \mathrm{~cm}$ depth as indicated by the phaeopigment and deeper sediment ${ }^{14} \mathrm{C}$-data. The offset of the intermediate and deep ${ }^{14} \mathrm{C}$-data may be due to Zoophycos or other macrofaunal activity. Below $1970 \mathrm{~m}$ water depth, the bioturbation horizon reaches beyond $7 \mathrm{~cm}$ depth and at $3010 \mathrm{~m}$ water depth it reaches below $10 \mathrm{~cm}$ depth. We suspect that the anomalously shallow mixing, according to pigment profile at the depths at $1970 \mathrm{~m}$ and $3010 \mathrm{~m}$ water depth may be due to the very low surficial OM concentrations at these depths. The constant age vs. depth relationship in the ${ }^{14} \mathrm{C}$ data at $1495 \mathrm{~m}$ is interpreted as a mass deposit such as a slump or turbidite, however, this event does not seem to be of very recent age as both the ${ }^{210} \mathrm{~Pb}$ and phaeopigment profiles imply that hemipelagic sedimentation has continued since than.

More targeted experiments are required to further examine our hypothesis of macrofaunal control on organic matter bioavailability to bacteria.

\section{Implications and conclusions}

Our data support the view that the enhanced preservation of OM occurs in the OMZ sediments where the BWO content is $<22 \mu \mathrm{M}$. The biochemical quality of the OM (phytopigments and amino acids) also shows a negative linear relationship with BWO content, implying that the OM in the OMZ sediments is indeed of high quality. In addition, the biochemical quality indicators correlate well with each other, thus providing a robust and consistent impression of the composition of OM in Arabian Sea sediments. However, in contradiction to the ruling paradigm of OM preservation in marine sediments, microbial bioavailability does not reflect the biochemical quality of OM in the OMZ. In light of recent literature (van Nugteren et al., 2009; Hunter et al., 2012), we propose that the enhanced preservation of OM in the Arabian Sea OMZ is controlled by the poorly developed, lowdiversity macrofaunal assemblage in this location. The lack of a well-developed macrofauna leads to inefficient breakdown of OM into smaller substrates more readily ingestible to bacteria. The proposed mechanisms would lead to preservation and burial of $\mathrm{OM}$ with high biochemical composition, thus providing an analogue for oil source rocks. 
Acknowledgements. The authors wish to acknowledge Clare Woulds and an anonymous reviewer for constructive criticism of the discussion paper. Tom Jilbert is thanked for proof reading the manuscript. The authors are grateful to Caroline Slomp for providing the ${ }^{210} \mathrm{~Pb}$ data. Peter van Breugel, Lennart van IJzerlo and Tanja Poortvliet are thanked for laboratory assistance. Ship time on R/V Pelagia was provided by the PASOM project financed by the Netherlands Organization for Scientific Research (NWO; grant number 817.01.015). The first and second author would like to acknowledge NWO-ALW (Earth and Life sciences council) for funding of their current research (grant numbers 820.01.011 and 835.20.043, respectively), the third author acknowledges funding from the European Science Foundation (grant number 855.01.130) and the fifth author from the Darwin Center of Biogeosciences.

Edited by: G. Herndl

\section{References}

Aller, R. C.: The effects of macrobenthos on chemical properties of marine sediment and overlying water, in: Animal-Sediment Relations, edited by: McCall, P. L. and Tevesz, M. J. S., Plenum, New York, NY, 53-102, 1982.

Aller, R. C.: Bioturbation and remineralization of sedimentary organic matter: effects of redox oscillation, Chem. Geol., 114, 331345, 1994.

Aller, R. C. and Aller, J. Y.: The effect of biogenic irrigation intensity and solute exchange of diagenetic reaction rates in marine sediments, J. Mar. Res., 56, 905-936, 1998.

Arnosti, C.: Speed bumps and barricades in the carbon cycle: Substrate structural effects on carbon cycling, Mar. Chem. 92, 263273, 2004.

Arnosti, C. and Holmer, M.: Carbon cycling in a continental margin sediment: Contrasts between organic matter characteristics and remineralization rates and pathways. Estuar. Coast. Shelf Sci., 58, 197-208, 2003.

Barranguet, C., Kromkamp, J., and Peene, J.: Factors controlling primary production and photosynthetic characteristics of intertidal microphytobenthos, Mar. Ecol. Prog. Ser., 173, 117-126, 1998.

Boschker, H. T. S., de Brouwer, J. F. C., and Cappenberg, T. E.: The Contribution of Macrophyte-Derived Organic Matter to Microbial Biomass in Salt-Marsh Sediments: Stable Carbon Isotope Analysis of Microbial Biomarkers, Limnol. Oceanogr., 44, 309$319,1999$.

Boer, W., Van den Bergh, G. D., De Haas, H., De Stigter, H. C., Gieles, R., and VanWeering, T. C. E.: Validation of accumulation rates in Teluk Banten (Indonesia) from commonly applied $\mathrm{Pb}$ 210 models, using the 1883 Krakatau tephra as time marker, Mar. Geol., 227, 263-277, 2006.

Bordovskiy, O. K.: Accumulation of organic matter in bottom sediments, Mar. Geol. 3, 33-82, 1965

Brussaard, L., Behan-Pelletier, V. M., Bignell, D. E., Brown, V. K., Didden, W., Folgarait P., Fragoso, C., Freckman, D. W., Gupta, V. V. S. R., Hattori, S. T., Hawksworth, D. L., Klopatek, C., Lavelle, P., Malloch, D. W., Rusek, J., Söderström, B., Tiedje, J. M., and Virginia, R. A.: Biodiversity and ecosystem functioning in soil, Ambio, 26, 563-570, 1997.
Canfield, D. E: Factors influencing organic carbon preservation in marine sediments, Chem. Geology, 114, 315-329, 1994.

Cowie, G. L. and Hedges, J. I.: The role of anoxia in organic matter preservation in coastal sediments: relative stabilities of the major biochemicals under oxic and anoxic depositional conditions, Org. Geochem, 19, 229-234, 1992.

Cowie, G. L. and Hedges, J. I.: Biochemical indicators of diagenetic alteration in natural organic matter mixtures, Nature 369, 304307, 1994.

Cowie, G. L. and Levin L. A.: Benthic biological and biogeochemical patterns and processes across an oxygen minimum zone (Pakistan margin, NE Arabian Sea), Deep-Sea Res. Pt. II, 56, 261270, 2009.

Cowie, G. L., Hedges, J. I., Prahl, F. G., and de Lance, G. J.: Elemental and major biochemical changes across an oxidation front in a relict turbidite: An oxygen effect, Geochim. Cosmochim. Acta, 59, 33-46, 1995.

Dauwe, B. and Middelburg, J. J.: Amino acids and hexosamines as indicators of organic matter degradation state in North Sea sediments, Limnol. Oceanogr., 43, 782-798, 1998.

Dauwe, B., Middelburg, J. J., Herman, P. M. J., and Heip, C. H. R.: Linking diagenetic alteration of amino acids and bulk organic matter reactivity, Limnol. Oceanogr., 44, 1809-1814, 1999.

Dauwe, B., Middelburg, J. J., and Herman, P. M. J.: Effect of oxygen on the degradability of organic matter in subtidal and intertidal sediments of the North Sea area, Mar. Ecol. Prog. Ser., 215, 1322, 2001.

Demaison, G. J. and Moore, G. T.: Anoxic environments and oil source bed genesis, Org. Geochem., 2, 9-31, 1980.

De Wit, R. and Bouvier, T.: "Everything is everywhere, but, the environment selects", What did Baas Becking and Beijerinck really say?, Environ. Microbiol., 8, 755-758, 2006.

Fenchel, T. and Finley, B.: The Ubiquity of Small Species: Patterns of Local and Global Diversity, Bioscience, 54, 777-784, 2004.

Fitznar, H. P., Lobbes, J. M., and Kattner, G.: Determination of enantiomeric amino acids with high-performance liquid chromatography and pre-column derivatisation with ophthaldialdehyde and $\mathrm{N}$-isobutyrylcysteine in seawater and fossil samples (mollusks), J. Chromatogr. A, 832, 123-132, 1999.

Gélinas, Y., Baldock, J. A., and Hedges, J. I.: Organic carbon composition of marine sediments: Effect of oxygen exposure on oil generation potential, Science, 294, 145-148, 2001.

Gooday, A. J., Levin, L. A., Aranda da Silva, A., Bett, B. J., Cowie, G. L., Dissard, D., Gage, J. D., Hughes, D. J., Jeffreys, R., Lamont, P. A., Larkin, K. E., Murty, S. J., Schumacher, S., Whitcraft, C., and Woulds, C.: Faunal responses to oxygen gradients on the Pakistan margin: A comparison of foraminiferans, macrofauna and megafauna, Deep-Sea Res. Pt. II, 56, 488-502, 2009.

Hargrave, B. T. and Phillips, G. A.: Annual in situ carbon dioxide and oxygen flux across a subtidal marine sediment, Estuar. Coast. Shelf Sci., 12, 725-737, 1981.

Hartnett, H. E., Keil, R. G, Hedges, J. I., and Devol, A. H.,: Influence of oxygen exposure time on organic carbon preservation in continental margin sediments, Nature, 391, 572-574, 1998.

Hedges, J. I. and Keil, R. G.: Sedimentary organic matter preservation: an assessment and speculative synthesis, Mar. Chem., 49, 81-115, 1995.

Hedges, J. I., Eglinton, G., Hatcher, P. G., Kirchman, D. L., Arnosti, C., Derenne, S., Evershed, R. P., Kögel-Knabner, I., De Leeuw, J. 
W., Littke, R., Michaelis, W., and Rullkötter, J.: The molecularlyuncharacterized component of nonliving organic matter in natural environments, Org. Geochem., 31, 945-958, 2000.

Henrichs, S. M.: Early diagenesis of organic matter in marine sediments: progress and perplexity, Mar. Chem. 39, 119-149, 1992.

Helly, J. J. and Levin, L. A.: Global distribution of naturally occurring marine hypoxia on continental margins, Deep-Sea Res. Pt. I, 51, 1159-1168, 2004

Hoppe, H.-G.: Microbial extracellular enzyme activity: a new ky parameter in aquatic ecology, in: Enzymes Microbial in Aquatic Environments, edited by: Chrost, R., J., Springer, Berlin, 60-83, 1991.

Hughes, D. J., Lamont, P. A., Levin, L. A., Packer, M., Feeley, K., and Gage, J. D.: Macrofaunal communities and sediment structure across the Pakistan margin Oxygen Minimum Zone, NorthEast Arabian Sea, Deep-Sea Res. Pt. II, 56, 434-448, 2009.

Hulthe, G., Hulth, S., and Hall, P. O. J.: Effect of oxygen on degradation rate of refractory and labile organic matter in continental margin sediments, Geochim. Cosmochim. Acta, 62, 1319-1328, 1998.

Hunter W. R., Veuger, B., and Witte U.: Macrofauna regulate heterotrophic bacterial carbon and nitrogen incorporation in lowoxygen sediments, ISME Journal, 6, 2140-2151, 2012.

Jeffrey, S. W. and Vesk, M.: Introduction to marine phytoplankton and their pigment signatures, in: Phytoplankton Pigments in Oceanography, edited by: Jeffrey, S. W., Mantoura, R. F. C., and Wright, S. W., UNESCO Publishing, Paris, 37-84, 1997.

Keil, R. G., Montlucon, D. B., Prahl, F. G., and Hedges, J. I.: Sorptive preservation of labile organic matter in marine sediments, Nature, 370, 549-552, 1994a.

Keil, R. G., Tsamakis, E., Fuh, C. B., Giddings, J. C., and Hedges, J. I.: Mineralogical and textural controls on the organic composition of coastal marine sediments: Hydrodynamic separation using SPLITT-fractionation, Geochim. Cosmochim. Acta, 58, 879893, 1994b.

Knicker, H.: Stabilization of N-compounds in soil and organicmatter-rich sediments - What is the difference?, Mar. Chem., 92, 167-195, 2004.

Kraal, P., Slomp, C. P., Reed, D. C., Reichart, G.-J., and Poulton, S. W.: Sedimentary phosphorus and iron cycling in and below the oxygen minimum zone of the northern Arabian Sea, Biogeosciences, 9, 2603-2624, doi:10.5194/bg-9-2603-2012, 2012.

Kristensen, E. and Mikkelsen, O. L.: Impact of the burrow-dwelling polychaete Nereis diversicolor on the degradation of fresh and aged macroalgal detritus in a coastal marine sediment, Mar. Ecol. Prog. Ser., 265, 141-153, 2003.

Levin, L. A.: Oxygen minimum zone benthos: Adaptation and community response to hypoxia: Oceanography and Marine Biology, Ann. Rev., 41, 1-45, 2003.

Levin, L. A., Whitcraft, C., Mendoza, G. F., Gonzalez ,J. P., and Cowie, G. L.: Oxygen and organic matter thresholds for benthic faunal activity on the Pakistan margin oxygen minimum zone (700-1100 m), Deep-Sea Res. Pt. II, 56, 449-471, 2009.

Leuschner, D. C., Sirocko, F., Grootes, P. M., and Erlenkeuser, H.: Possible influence of Zoophycos bioturbation on radiocarbon dating and environmental interpretation, Mar. Micropaleontol., 46, 111-126, 2002.

Mayer, L. M.: Surface area control of organic carbon accumulation in continental shelf sediments, Geochim. Cosmochim. Acta, 58,
1271-1284, 1994.

Mayer, L. M., Jumars, P. A., Bock, M. J., Vetter, Y. -A., and Schmidt, J. L.: Two roads to Sparagmos: Extracellular digestion of sedimentary food by bacterial inoculation versus depositfeeding, in: Organism - Sediment Interactions, edited by: Aller, J. Y., Woodin, S. A., and Aller, R. C., University of South Carolina Press, Columbia, 335-347, 2001.

Middelburg, J. J., Barranguet, C., Boschker, H. T. S., Herman, P. M. J., Moens, T., and Heip, C. H. R.: The fate of intertidal microphytobenthos carbon: An in situ 13C-labeling study, Limnol. Oceanogr., 45, 1224-1234, 2000.

Moodley, L., Nigam, R., Ingole, B., Prakash Babu, C., Panchang, R., Nanajkar, M., Sivadas, S., van Breugel, P., van Ijzerloo, L., Rutgers, R., Heip, C. H. R., Soetaert, K., and Middelburg, J. J.: Oxygen minimum seafloor ecological (mal) functioning, J. Exp. Mar. Biol. Ecol., 398, 91-100, 2011.

Nieuwenhuize, J., Maas, Y. E. M., and Middelburg, J. J.: Rapid analysis of organic carbon and nitrogen in particulate materials, Mar. Chem. 44, 217-224, 1994.

Pedersen, T. F. and Calvert, S. E.: Anoxia vs. productivity: what controls the formation of organic- carbon-rich sediments and sedimentary rocks?, AAPB Bull., 74, 454-466, 1990.

Pozzato, L.,: Prokaryotic, protozoan and metazoan processing of organic matter in sediments: a tracer approach, PhD. Thesis, Royal Netherlands Institute for Sea Research-Yerseke, Utrecht University, the Netherlands, 2012

Premuzic, E., T., Benkovitz, C., M., Gaffney, J. S., and Walsh, J. J.: The nature and distribution of organic matter in the surface sediments of world oceans and seas, Org. Geochem. 4, 63-77, 1982.

Reichart, G. J., Lourens, L. J., and Zachariasse, W. J.: Temporal variability in the northern Arabian Sea oxygen minimum zone (OMZ) during the last 225000 years, Paleoceanography 13, 607621, 1998.

Rothman, D. H. and Forney, D. C.: Physical model for the decay and preservation of marine organic carbon, Science, 316, 13251328, 2007.

Slater, R. D. and Kroopnick, P.: Controls on dissolved oxygen distribution and organic carbon deposition in the Arabian Sea, in: Marine Geology and Oceanography of Arabian Sea and Coastal Pakistan, edited by: Haq, B. U. and Milliman, J. D., Van Nostrand Reinhold/Scientific and Academic Editions, New York, 305-313, 1984.

Stuiver, M. and Reimer, P. J.: Extended C-14 data-base and revised Calib 3.0 C-14 age calibration program, Radiocarbon, 35, 215230, 1993.

Turley, C. M., Bianchi, M., Christaki, U., Conan, P., Harris, J. R. W., Psarra, S., Ruddy, G., Stutt, E. D., Tselepides, A., and Van Wambeke, F.: Relationship between primary producers and bacteria in an oligotrophic sea - The Mediterranean and biogeochemical implications, Mar. Ecol-Prog. Ser., 193, 11-18, 2000.

Tyson, R. V.: Sedimentary Organic Matter - Organic Facies and Palynofacies. Chapman and Hall, London, 1995.

Van der Weijden, C. H., Reichart, G.-J., and Jan Visser, H.: Enhanced preservation of organic matter in sediments deposited within the oxygen minimum zone in the northeastern Arabian Sea, Deep-Sea Res. Pt. I, 46, 807-830, 1999.

Vandewiele, S., Cowie, G., Soetaert, K., and Middelburg, J. J.: Amino acid biogeochemistry and organic matter degradation 
state across the Pakistan margin oxygen minimum zone, DeepSea Res. Pt. II, 56, 376-392, 2009.

Van Nugteren, P., Herman, P. M. J., Moodley, L., Middelburg, J. J., Vos, M., and Heip, C. H. R.: Spatial distribution of detrital resources determines the outcome of competition between bacteria and a facultative detritivorous worm, Limnol. Oceanogr., 54, 1413-1419, 2009.

Wei, C.-L., Rowe, G. T., Briones, E. E., Boetius, A., Soltwedel, T., Caley, M. J., Soliman, Y., Huettmann, F., Qu, F., Yu, Z., Pitcher, C. R., Haedrich, R. L., Wicksten, M. K., Rex, M. A., Baguley, J. G., Sharma, J., Danovaro, R., MacDonald, I. R., Nunnally, C. C., Deming, J. W., Montagna, P., Lévesque, M., Weslawski, J. M., Wlodarska-Kowalczuk, M., Ingole, B. S., Bett, B. J., Billett, D. S. M., Yool, A., Bluhm, B. A., Iken, K., and Narayanaswamy, B. E.: Global patterns and predictions of seafloor biomass using random forests: PLoS ONE, 5, e15323, doi:10.1371/journal.pone.0015323, 2010.
Weiss, M. S., Abele, U., Weckesser, J., Welte, W., Schiltz, E., and Schulz, G. E.: Molecular architecture and electrostatic properties of a bacterial porin, Science, 254, 1627-1630, 1991.

Witte, U., Aberle, N., Sand, M., and Wenzhöfer, F.: Rapid response of a deep-sea benthic community to POM enrichment: an in situ experimental study, Mar. Ecol. Prog. Ser., 251, 27-36, 2003.

Woulds, C. and Cowie, G. L.: Sedimentary pigments on the Pakistan margin: Controlling factors and organic matter dynamics, DeepSea Res. Pt. II, 56, 347-357, 2009.

Woulds, C., Middelburg, J. J., and Cowie, G. L.: Alteration of organic matter during infaunal polychaete gut passage and links to sediment organic geochemistry, Part I, Amino acids, Geochim. Cosmochim. Acta, 77, 396-414, 2012.

Wyrtki, K.: Physical Oceanography of the Indian Ocean, in: The Biology of the Indian Ocean, edited by: Zeitschel, B., Springer, New York, 18-36, 1973. 